Ig-G-Globulin-Fraktion $A_{1} F_{1}$ erschwert die zwischen Protein und Ionen des Lösungsmittels auftretende Wechselwirkung eine Adsorption an die Zellmembran ${ }^{24}$. Im Serum treten dagegen andere Proteine, die selbst die elektrophoretische Beweglichkeit der Zellen nicht beeinflussen, in diese Wechselbeziehungen ein und verhindern so die Salzwirkung. Dementsprechend ${ }^{1}$ konnten wir durch Chromatographie an DEAE-Sephadex eine weitere Fraktion $\mathrm{A}_{2} \mathrm{~F}_{1}$ gewinnen, die bei der Ionenstärke 0,15 die Beweglichkeit von L-Zellen nicht verlangsamte, jedoch zusammen mit $\mathrm{A}_{1} \mathrm{~F}_{1}$, das bei dieser Ionenstärke nicht wirksam war, membranaktiv war. Dieser Befund führte zu der Annahme, daß zumindest zwei verschiedene Proteine für die Wirksamkeit des Serums auf die elektrophoretische Beweglichkeit von L-Zellen notwendig sind; eine starke Konzentrationserhöhung

24 W. Piper u. G. Ruhenstroth-Bauer, Klin. Wschr. 34, 11 [1956]. von $A_{1} F_{1}$ kann jedoch den Effekt der Ionenstärke ausgleichen. Auch bei Inkubation der Zellen mit Serum ist vorwiegend die Adsorption der wirksamen Ig-G-Globulinfraktion $A_{1} F_{1}$ für die Verlangsamung der elektrophoretischen Beweglichkeit der Zellen verantwortlich, wie die Untersuchung des Uberstandes nach Waschen in physiologischer Kochsalzlösung zeigt.

Die Thermolabilität der verlangsamenden Wirkung im Serum läßt sich durch unspezifische Aggregation zwischen thermolabilen Serumproteinen und elektrophoretisch membranaktivem Ig-G-Globulin erklären. Auch der Aktivitätsverlust des Serums nach Dialyse gegen ein ionenschwaches Medium könnte auf einem ähnlichen Aggregationsmechanismus beruhen.

Frl. B. DÜRR und Herrn L. Uher danken wir für wertvolle technische Assistenz.

\title{
On Metastable States of Carotenoids in Primary Events of Photosynthesis
}

\author{
- Registration by repetitive ultra-short-flash photometry -
}

Ch. WolfF and H. T. WitT

Max-Volmer-Institut, I. Institut für Physikalische Chemie, Technische Universität Berlin

(Z. Naturforschg. 24 b, 1031-1037 [1969] ; eingegangen am 10. März 1969)

\begin{abstract}
A repetitive ultra-short-flash photometer is described which can resolve absorption changes of $0,01 \%$ in the time range of $10^{-7} \mathrm{sec}$. With this instrument the following results have been obtained. Air-saturated suspensions of photosynthetic systems show light induced absorption changes with a decay time of $\tau_{1 / 2} \cong 3 \cdot 10^{-6}$ sec. The properties of absorption changes indicate that they are caused by a metastable state.

The difference spectrum of the changes are characterized by peaks at $430,460,490$ and $520 \mathrm{~nm}$. No absorption changes are observed in the red region! Therefore the metastable state is formed by carotenoids.

Excitation of chlorophyll sensitizes the formation of the metastable state of the carotenoid. Therefore a transfer of energy from chlorophyll to carotenoid has to be assumed.

The desactivation of the metastable state represents probably an energy valve reaction.
\end{abstract}

1. 1958 we reported on a special type of absorption changes in photosynthesis with a decay time of $\sim 10^{-5}$ sec. The difference spectrum shows a negative peak at $430 \mathrm{~nm}$ with a shoulder at $460 \mathrm{~nm}$ (in chlorella also at $490 \mathrm{~nm}$ ) and a positive peak at $520 \mathrm{~nm}^{1,2}$. We called it "type 1 ".

1 H. T. Witt, R. Moraw, and A. Müller, Z. physik. Chem. N.F. 14, 127 [1958]; H. T. WITT, R. MORAW, and A. MÜlleR, Z. Naturforschg. 13 b, 822 [1958].

2 R. Moraw and H. T. Witt, Z. physik. Chem. N.F. 29, 1 [1961].
2. Type 1 occurs at temperatures between $\leqq-160^{\circ} \mathrm{C}$ and $+60{ }^{\circ} \mathrm{C}^{3}$.

3. Type $\mathrm{l}$ can be quenched by paramagnetic gases $\left(\mathrm{O}_{2}, \mathrm{NO}\right)^{3}$.

4. Type 1 increases also above the saturating light energy of photosynthesis $1,3,4$.

3 G. Zieger, A. Müller, and H. T. Witt, Z. physik. Chem. N.F. 29, 13 [1961].

${ }^{4}$ R. Moraw, Thesis, Universität Marburg 1960. 
It was concluded that type 1 is caused by the formation of a metastable state of a special chlorophyll-a.

In the meantime further measurements have been reported in l. c. ${ }^{5-8}$. Mathis observed in the difference spectrum also negative peaks of absorption changes at 430 and $490 \mathrm{~nm}^{7}$, but he found not the peak which we observed at $460 \mathrm{~nm}$. He reported furthermore on a $\mathrm{O}_{2}$-dependency of the decay time ${ }^{8}$. According to this result the quenching of type 1 by $\mathrm{O}_{2}$ reported in l. c. ${ }^{3}$. is a dynamic quenching.

\section{Results}

Using the very fast and sensitive repetitive ultrashort-flash photometry (see below) we refined our measurements and found the following new results on type 1. (Primary notes in 1. c. ${ }^{9,10}$.)

5 . The half rise time of the absorption changes of type 1 is evaluated within

$$
<5 \cdot 10^{-7} \mathrm{sec}
$$

(see fig. 1).

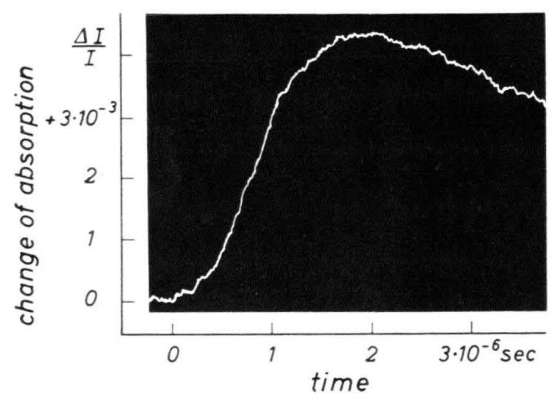

Fig. 1. Rise of the absorption change of type 1 as function of time at $\lambda=515 \mathrm{~nm}$ in a suspension of spinach chloroplasts. To quench all absorption changes which are caused by electrons, protons and electrical fields, photosynthesis was blocked by addition of $5 \cdot 10^{-6} \mathrm{M}$ DCMU. This has no influence on the kinetics of type 1 . Chlorophyll content: $5 \cdot 10^{-6} \mathrm{M}$. Tris-buffer: $5 \cdot 10^{-2} \mathrm{M} . \mathrm{pH}=7,2$. Electron acceptor: $10^{-4} \mathrm{M}$ benzyl viologene (for preventing the cyclic electron flow at the light reaction I). Temperature: $22^{\circ} \mathrm{C}$. Optical path: $78 \mathrm{~mm}$. Exci-

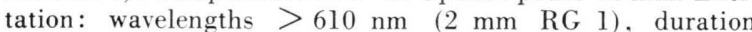
$4 \cdot 10^{-7} \mathrm{sec}$, repetitive ultra-short-flash technique, frequency $10 \mathrm{cps}, 1200$ flashes were fired. Measuring light: $515 \mathrm{~nm}$, grating monochromator, halfwidth $10 \mathrm{~nm}$. The measured rise time is equal to the rise time of the apparatus (including flash).

5 W. W. Hildreth, M. Avron, and B. Chance, Plant Physiol. 41, 983 [1966].

6 W. W. Hildreth, Biochim. biophysica Acta [Amsterdam] 153, 197 [1968].
6. The decay time (half-life) of the changes of type 1 amounts to

$$
\tau_{1 / 2}=(3,5 \pm 1) \cdot 10^{-6} \mathrm{sec}
$$

in air-saturated aqueous suspensions (see fig. 2) . This value is the same during photosynthesis in spinach chloroplasts as well as in chlorella cells.

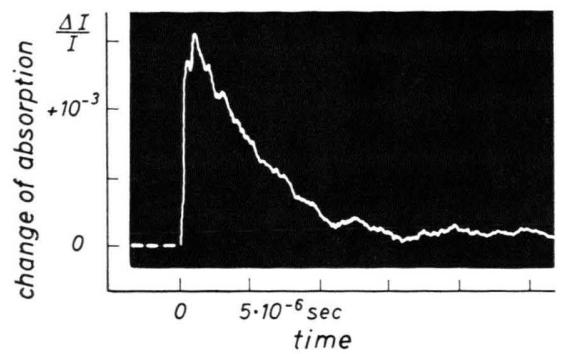

Fig. 2. Time course of the absorption change of type 1 at $\lambda=515 \mathrm{~nm}$ in a suspension of Chlorella vulgaris. To quench all absorption changes which are caused by electrons, protons and electrical fields, photosynthesis was blocked by heattreating of the cells $\left(5 \mathrm{~min}\right.$ at $\left.55^{\circ} \mathrm{C}\right)$. This has no influence on the kinetics of type 1 . Chlorophyll content: $4,9 \cdot 10^{-6} \mathrm{M}$. Carbonate-buffer: $8 \cdot 10^{-2} \mathrm{M}, \mathrm{pH}=9,1$.. Temperature : $22^{\circ} \mathrm{C}$. Optical path: $78 \mathrm{~mm}$. Excitation: wavelengths $>620 \mathrm{~nm}$ (4 mm RG 1). Duration $4 \cdot 10^{-7} \mathrm{sec}$, repetitive ultra-shortflash technique, frequency $10 \mathrm{cps}, 4350$ flashes were fired. Measuring light: $516 \mathrm{~nm}$, interference line filter, halfwidth $13 \mathrm{~nm}$.

There is also no difference in the decay time when photosynthesis is blocked by addition of DCMU * $^{*}$ in chloroplasts or by heat-treatment of chlorella cells $\left(5 \mathrm{~min}\right.$ at $\left.55^{\circ} \mathrm{C}\right)$, see table 1 .

$\begin{array}{cc}\text { Sample } & \tau_{1 / 2} \\ \text { (air-saturated aqueous suspension) } & \text { of type } 1 \\ {\left[10^{-6} \mathrm{sec}\right.}\end{array}$

Spinach chloroplasts

$3,5 \pm 1$

(intact electron transport)

Spinach chloroplasts

(electron transport blocked by DCMU)

Cells of Chlorella vulgaris

(intact photosynthesis)

Cells of Chlorella vulgaris (photosynthesis $\quad 3,5 \pm 1$ quenched by heat-treatment $5 \mathrm{~min}$ at $55^{\circ} \mathrm{C}$ )

Table 1. Half-life of type 1 in various photosynthetic systems.

The decay time increases up to $7 \cdot 10^{-6} \mathrm{sec}$ when the oxygen content of the suspension is lowered, e.g. by addition of $\mathrm{Na}_{2} \mathrm{~S}_{2} \mathrm{O}_{4}$ or when the mobility of the

7 P. Mathis, C. R. hebd. Séances Acad. Sci. Sér. D 263, 1770 [1966].

8 P. Mathis, C. R. hebd. Séances Acad. Sci. Sér. D 264, 1903 [1967].

* DCMU $=$ 3-(3,4-dichlorophenyl)-1,1-dimethylurea. 


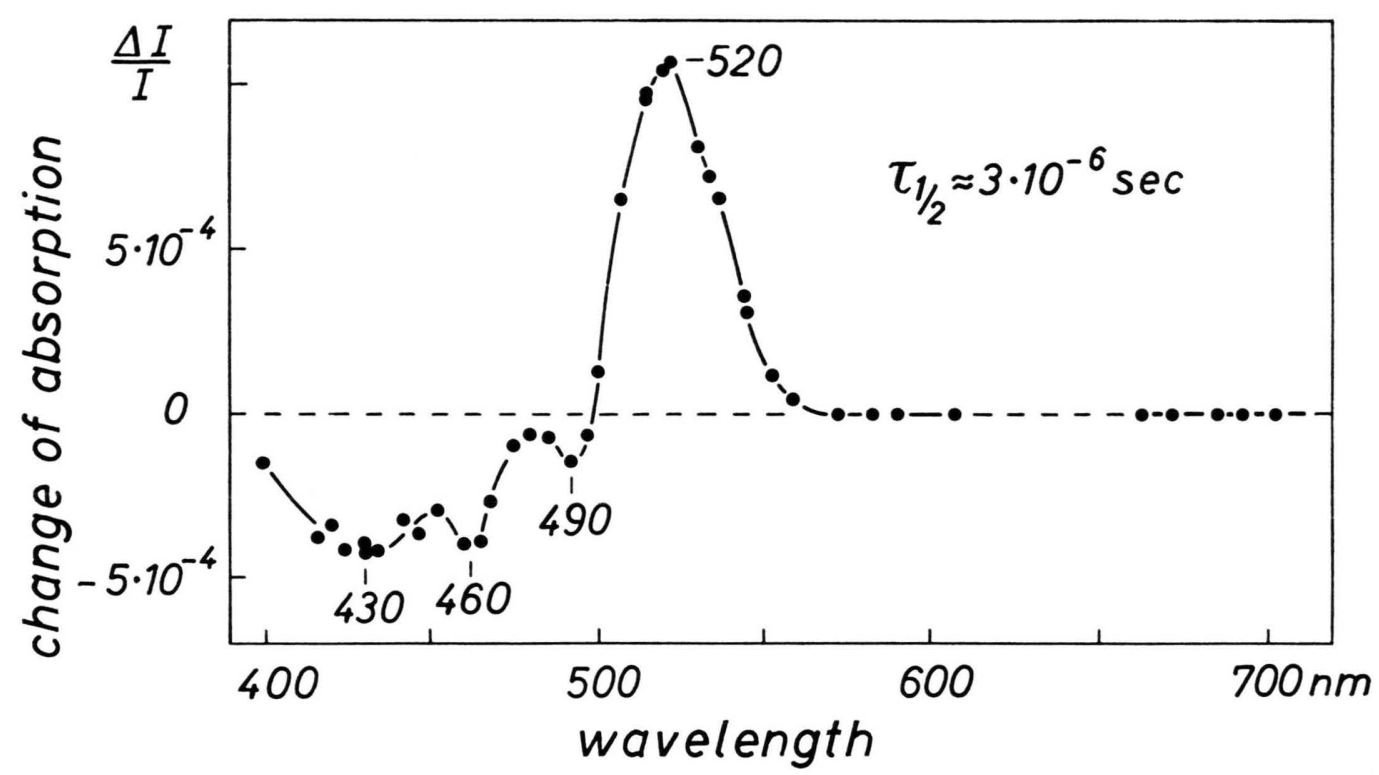

Fig. 3. Absorption changes of type 1 (decay time of $\approx 3 \cdot 10^{-6} \mathrm{sec}$ ) in a suspension of spinach chloroplasts as a function of wavelength. To quench all absorption changes which are caused by electrons, protons and electrical field, photosynthesis was blocked by addition of $2 \cdot 10^{-6} \mathrm{M}$ DCMU. This has no influence on the kinetics of type 1 . Chlorophyll content: $1,7 \cdot 10^{-6} \mathrm{M}$. Tris-buffer: $5 \cdot 10^{-2} \mathrm{M}, \mathrm{pH}=7,2$. Electron acceptor: $10^{-4} \mathrm{M}$ benzylviologene (for preventing the cyclic electron flow at the light reaction I). Temperature: $22^{\circ} \mathrm{C}$. Optical path: $78 \mathrm{~mm}$. Excitation: wavelengths $>610 \mathrm{~nm}(2 \mathrm{~mm} R G$ l). Duration $4 \cdot 10^{-7} \mathrm{sec}$, repetitive ultra-short-flash technique, frequency $10 \mathrm{cps}, 4500$ flashes were fired per each measuring point. Measuring light, grating monochromator, half-width $10 \mathrm{~nm}$.

oxygen molecules is lowered by using glycerol instead of the aqueous solution. In l. c. ${ }^{7}$ a decay time of $3 \cdot 10^{-6}$ sec was found in glycerol.

7. The refined difference spectrum of type 1 shows in comparison with our first spectrum ${ }^{2}$ besides the peak at $430 \mathrm{~nm}$ a more pronounced change at $460 \mathrm{~nm}$ and at $490 \mathrm{~nm}$ and no absorption changes in the red region (see fig. 3 ).

8. The magnitude of the changes at $515 \mathrm{~nm}$ in dependence of the flash energy is depicted in fig. 4 . The changes with the decay of $\tau_{1 / 2} \approx 3 \cdot 10^{-6}$ sec represent type 1.

At $515 \mathrm{~nm}$ occur, however, also absorption changes of another reaction with $\tau_{1 / 2} \gtrsim 10^{-3}$ sec. They reflect strictly primary events (electrical field changes) in photosynthesis ${ }^{11,12}$ because, for instance, both photosynthesis and these field indicating absorption changes are saturated at higher flash energy (fig. 4 top) and because both simul-

9 H. T. WITT, in: Fast Reactions and Primary Processes in Chemical Kinetics (Nobel Sympos. V). Ed. S. Claesson, p. 261, Almqvist \& Wiksell, Stockholm 1967; Interscience Publ., New York, London, Sydney.

10 Ch. Wolff, H.-E. Buchwald, H. Rüppel, and H. T. Witt, Naturwissenschaften 54, 487 [1967]. taneously disappear by addition of the poison DCMU (see fig. 4) etc.

In contrast to this behaviour of the field indicating changes the changes of type 1 increase with increasing energy also above the saturating flash energy of photosynthesis. In fig. 4 top, no saturating of type 1 is observed in an energy range ten times higher than the energy which saturates photosynthesis or the field indicating changes respectively.

9. The changes of type 1 do not disappear after blocking photosynthesis with DCMU (this corresponds to the behaviour at $-160{ }^{\circ} \mathrm{C}$ (see l. c. ${ }^{2}$ )) . With addition of DCMU they are even greater than during photosynthesis (see fig. 4).

The results in item $6,8,9$ are contrary to the measurements of HiLDRETH et al. 5, ${ }^{-6}$. HILDRETH et al. observed a decay time of $4-6 \cdot 10^{-6} \mathrm{sec}$ and reported that the magnitude of the absorption changes of type 1 is decreased by addition of DCMU and this already at a DCMU-concentration which does not cause a total

11 W. Junge and H. T. WITT, Z. Naturforschg. 23 b, 244 [1968].

12 H. T. Witt, B. Rumberg, and W. Junge, 19. Mosbach Colloquium, p. 262, Springer-Verlag, Berlin, Göttingen, Heidelberg 1968. 


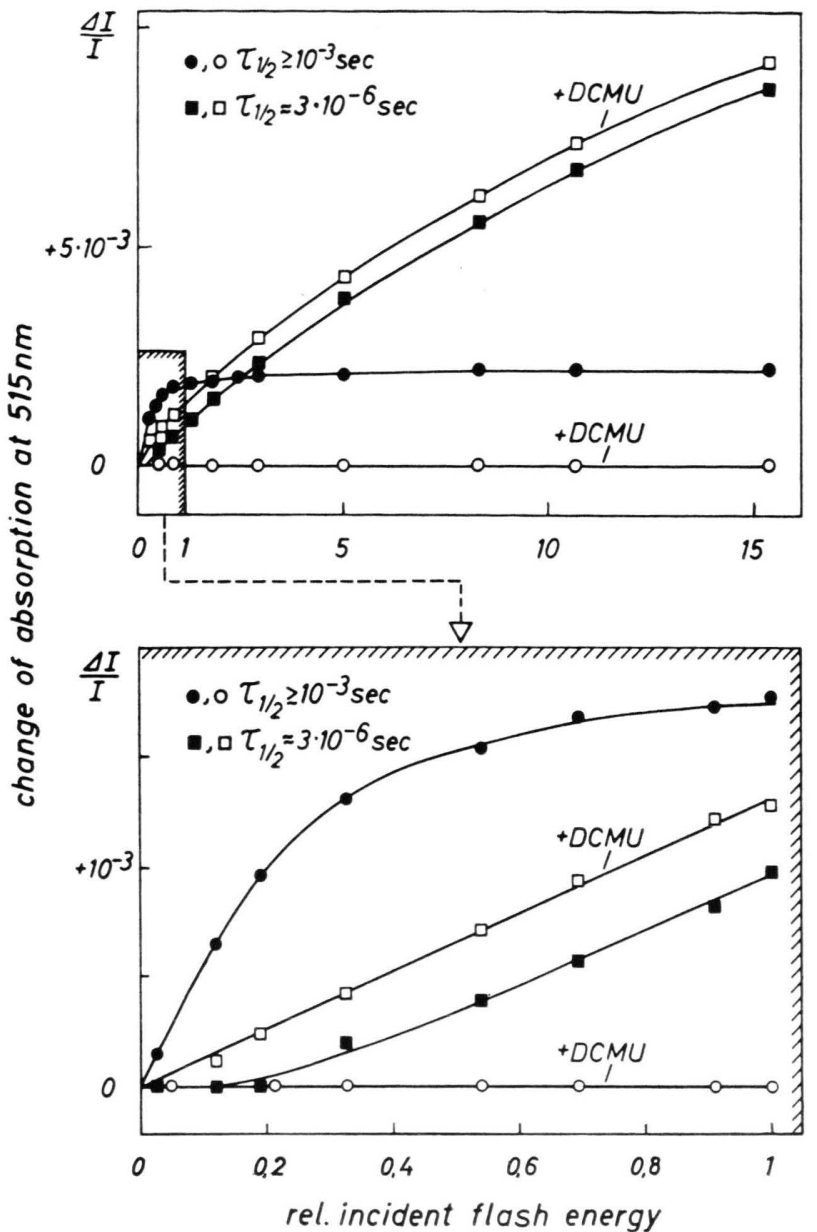

Fig. 4. Top: Absorption changes of type $1\left(3 \cdot 10^{-6} \mathrm{sec}\right)$ and field indicating absorption changes ( $\left.\gtrsim 10^{-3} \mathrm{sec}\right)$ at $515 \mathrm{~nm}$ as a function of incident flash energy in a suspension of spinach chloroplasts. Bottom: Hatched area in the top picture enlarged. The measurements have been carried out during photosynthesis $(\bullet)$ and when photosynthesis was quenched by addition of $2 \cdot 10^{-6}$ M DCMU $(\bigcirc, \square)$. Chlorophyll content: $4 \cdot 10^{-6} \mathrm{M} . \mathrm{O}_{2}$-activity: $159 \frac{\mathrm{M}\left(\mathrm{O}_{2}\right)}{\mathrm{M}(\mathrm{Chl}) \cdot \mathrm{h}}$. Electron acceptor : $10^{-4} \mathrm{M}$ benzylviologene, phosphorylation uncoupler : $2 \cdot 10^{-3} \mathrm{M}$ $\mathrm{NH}_{4} \mathrm{Cl}$. Temperature: $22{ }^{\circ} \mathrm{C}$. Optical path: $78 \mathrm{~mm}$. Excitation: wavelengths $>610 \mathrm{~nm}\left(2 \mathrm{~mm} \mathrm{RG} \mathrm{1)}\right.$, duration $7,5 \cdot 10^{-7}$ sec (top) resp. $4 \cdot 10^{-7} \mathrm{sec}$ (bottom). Each measuring point is the average of $5-10$ signals. Measuring light: $516 \mathrm{~nm}$, interference filter, halfwidth $13 \mathrm{~nm}$.

blocking of photosynthesis. Furthermore they measured saturation curves, similar to those of the slower phase (field indicating) which is also contrary to the results in fig. 4 .

\section{Discussion}

It is clear that the change of type 1 is not caused by a chemical intermediate in the electron transport chain of photosynthesis. This follows from the fact that absorption changes are observable also when the electron transfer is totally blocked (at $-160{ }^{\circ} \mathrm{C}$ or with addition of DCMU). Probably type 1 is caused by an excited energy trap.

The decay of type 1 within $\approx 3 \cdot 10^{-6} \mathrm{sec}$ is, however, not caused by the energy transfer from such excited traps to the photoactive chlorophyll- $\mathrm{a}_{1}$ or $-a_{I I}$ in the electron transport chain. This follows from the fact that the primary events of chloro-

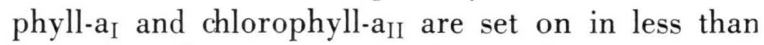
$2 \cdot 10^{-8} \sec ^{13}$. Therefore the decay of type 1 within $3 \cdot 10^{-6}$ sec reflects probably a valve reaction. Because the decay time depends on the $\mathrm{O}_{2}$-content it has to be assumed that the desactivation of the excited traps is caused partly by $\mathrm{O}_{2}{ }^{3}$.

It is supposed that when photosynthesis is becoming saturated with increasing flash energies, more antennae chlorophyll is excited than used for photosynthesis. Part of these excited antennae states transfers energy to the chlorophyll-a $\mathrm{a}_{\mathrm{I}}$ and chlorophyll-a $\mathrm{a}_{\text {II }}$ within a time which is as fast as the rise time of the primary events $\left(<2 \cdot 10^{-8} \mathrm{sec}\right)$ and which cannot be resolved with the apparatus described here.

The energy of the superfluous excited antennae states are transferred to the assumed traps. According to fig. 1 this must take place in $<5 \cdot 10^{-7}$ sec.

The excited traps are desactivated in air-saturated aqueous suspensions partly by $\mathrm{O}_{2}$ in $3 \cdot 10^{-6}$ sec (see fig. 2). It may be that the triplet ${ }^{3} \mathrm{O}_{2}$ is converted during this reaction into a singlet ${ }^{1} \mathrm{O}_{2}$.

If photosynthesis is blocked with addition of DCMU no energy is transferred to chlorophyll-a ${ }_{I}$ and chlorophyll-a II . Therefore all energy is channeled to the traps and the changes of type 1 are greater with DCMU than without DCMU (see fig. 4).

What is the physical nature and the chemical constitution of such traps?

It was demonstrated by us in l. c. ${ }^{3}$ (see 2 and 3 ) and confirmed in l.c. ${ }^{8}$ that type 1 is a metastable state. From the negative absorption change at $430 \mathrm{~nm}$ in l.c. ${ }^{1,2}$ we assumed that a chlorophyll-a is in action. From the negative peak at $490 \mathrm{~nm}$ Mathis discussed that additionally a carotenoid may be in

13 Ch. WolfF, K. Witt, and H. T. WItT, in preparation. 
action $^{7,8,14}$. Different types of carotenoids have, however, an absorption with three characteristic bands between $400-500 \mathrm{~nm}^{15}$. Therefore the action of carotenoids should cause three negative peaks. In our refined difference spectrum in fig. 3 we have observed three pronounced negative absorption changes at $430 \mathrm{~nm}, 460 \mathrm{~nm}$, and $490 \mathrm{~nm}$. From this result it seems probably that these changes are caused by the formation of metastable states of carotenoids.

According to this assumption the positive change at $520 \mathrm{~nm}$ must belong to the absorption band of the metastable carotenoid. This is in accordance with the fact that during the light induced reaction of carotenoids in hexane a new absorption band at $514 \mathrm{~nm}$ has been observed which probably belongs to a metastable state (triplet) of the carotenoids ${ }^{\mathbf{1 6}}$. So, our results may be interpreted in respect to the carotenoids in the following way.

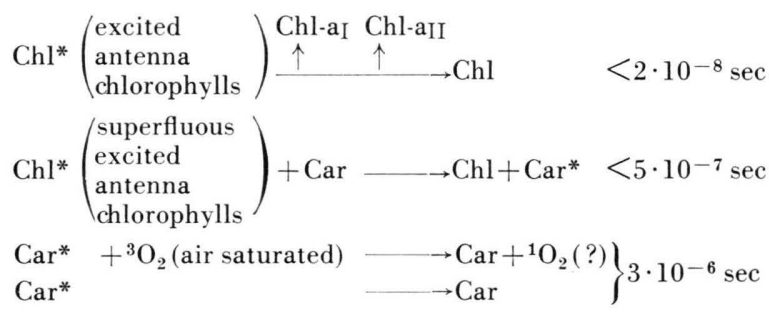

The negative absorption changes at $430 \mathrm{~nm}$ in fig. 3 may be caused besides by carotenoids by a reaction of a chlorophyll-a as has been assumed in l. c. ${ }^{1,2}$. (Chl-a has an absorption band at $430 \mathrm{~nm}$.) This can be decided by measurements of absorption changes in the red region between $660-700 \mathrm{~nm}$. In this spectral range the chlorophyll-a has a further absorption band but not the carotenoids. According to fig. 3 no changes of $3 \cdot 10^{-6} \mathrm{sec}$ do occur in this region. Therefore we have to assume that the difference spectrum in fig. 3 is exclusively caused by carotenoids. Because the absorption changes have

14 P. Mathis, Internat. Congress of Photosynthesis Research, Freudenstadt (1968), in press.

15 P. Karrer and E. JUCKer, in: Carotenoide, Ed. BirkhäU. SER, Basel 1948.

16 M. Chessin, R. Livingston, and T. G. Truscott, Trans. Faraday Soc. 62, 1519 [1966].

28 H. E. BUCHWALD and H. RÜPPEL, Nature [London] 220, 57 [1968].

29 H. E. Buchwald and Ch. Wolff, in preparation.

17 H. T. WITT, in: Fast Reactions and Primary Processes in Chemical Kinetics (Nobel Sympos. V). Ed. S. Clatesson, p. 81, Almqvist \& Wiksell, Stockholm 1967; Interscience Publ. New York, London, Sydney. been induced by red flash light, absorbed only by chlorophylls, it can be followed that the excitation energy is transfered from chlorophyll to carotenoids (probably triplet-triplet transfer).

The measurements in the red spectral range (see fig. 3 ) in the time range of $3 \cdot 10^{-6} \mathrm{sec}$ are extremely difficult because at the same wavelength a strong chlorophyll fluorescence takes place. Therefore a special apparatus has been developed by which fluorescence can be completely separated from fast absorption changes ${ }^{28}$. On such results will be reported in detail in a following paper ${ }^{29}$.

\section{The repetitive ultra-short-flash photometry apparatus}

For analysis of the mechanism of fast photochemical and chemical reactions the repetitive pulse technique has been introduced. By this method the time resolution and sensitivity can be increased by a factor 100 in comparison with the single pulse technique. In this way, a number of new data, intermediates and reaction mechanisms have been detected in photosynthesis and other fields.

Since 1962 five different types of repetitive apparatuses have been developed for the different time regions down to $10^{-8}$ sec. A summary with short descriptions and examples are given in $1 .{ }^{17}{ }^{17}$, details in l. c. ${ }^{18-21}$.

In this report the repetitive ultra-short-flash photometry for the $10^{-5}-10^{-7} \mathrm{sec}$ range is described and in the following paper the repetitive laser giant pulse photometry for the $10^{-6}-10^{-8} \mathrm{sec}$ time range ${ }^{22}$.

For the analysis of reactions in the $10^{-5}-10^{-7}$ sec range flashes with $10^{-7} \mathrm{sec}$ emission time must be used. Such short pulses can be realized only with small flash energies which produce a very small chemical turn-over. Further the necessary bandwidth of the apparatus causes such a considerable noise,

18 H. Rüppel, Thesis, Unversität Marburg 1962; H. RüppeL, V. Bültemann, and H. T. WitT, Ber. Bunsenges. physik. Chem. 68, 340 [1964].

19 G. Döring, H. H. Stiehl, and H. T. Witt, Z. Naturforschg. 22 b, 639 [1967].

20 P. BRumm and H. Rüppel, Z. Naturforschg. 22 b, 980 [1967] ; P. Brumm, F. P. Kilian, and H. Rüppel, Ber. Bunsenges. physik. Chem. 7, 1085 [1968].

21 H. RüPPEL and H. T. WITT, Methods in Enzymology, in: Fast Reactions, Ed. S. P. Colowick and N. O. Kaplan, Acad. Press Inc., New York 1969, in press.

22 Ch. Wolff, H.-E. Buchwald, H. Rüppel, K. Witt, and H. T. Witt, Z. Naturforschg. 24 b, 1038 [1969]. 


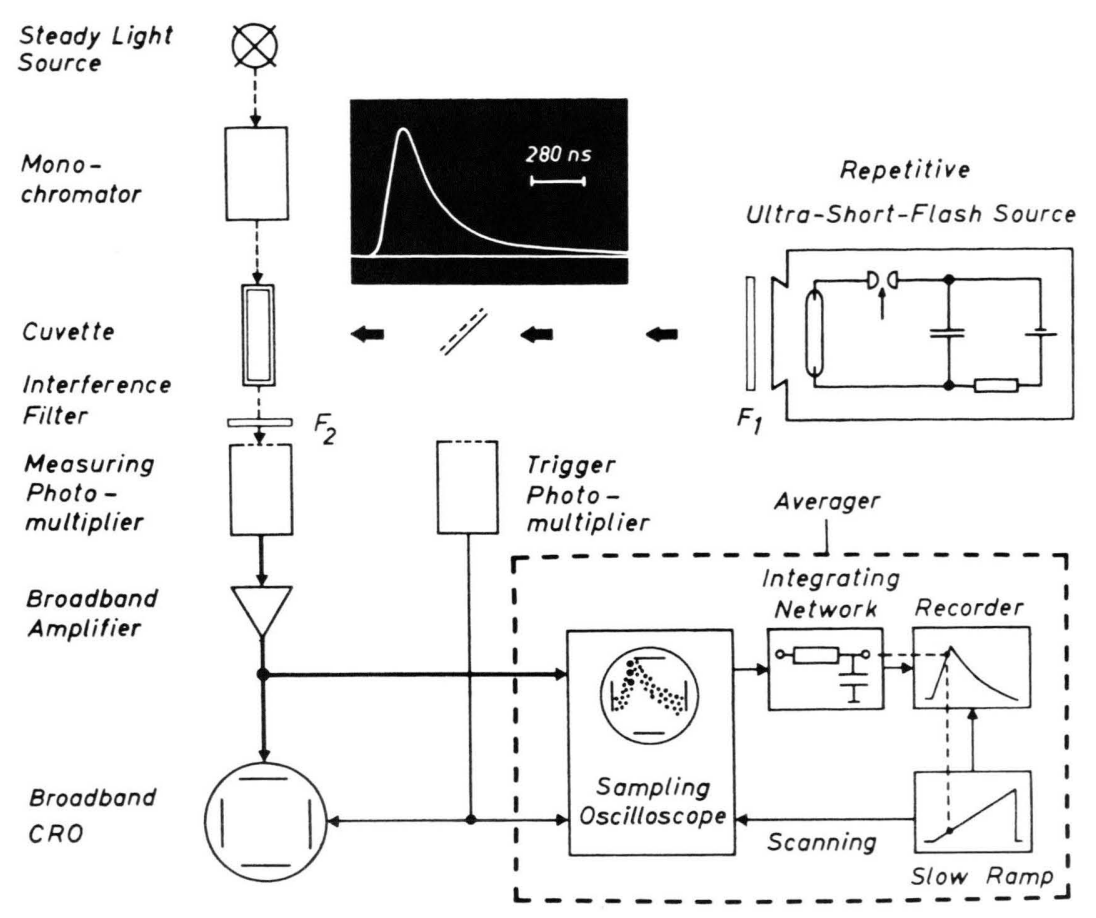

that no signal can be observed. By using the repetitive pulse technique, however, these difficulties can be settled (primary note see l.c. ${ }^{10,17}$ ) (see fig. 5).

Excitation: The photochemical systems are excited by the ultra short flashes from the flashlamp PEK XE 9-3 (fig. 5). The electrical energy for the discharge is stored at a high voltage (up to $16 \mathrm{kV}$ ) in a capacitor with low capacity $(10-30 \mathrm{nF})$. The flashlamp is fired in series with a triggered spark gap (EGG GP 12A), The duration of the flash in fig. 5 is $280 \mathrm{~ns}$. The flashes are generated repetitively with a frequency up to $20 \mathrm{cps}$. The electrical input is about 2 joules. The flash light is transferred by an elliptical mirror into the cuvette. Using a colour filter $F_{1}(\lambda>600 \mathrm{~nm})$ an optical energy of about $2 \cdot 10^{-3}$ joule per flash enters the cuvette which is sufficient for saturating photosynthesis. [For special investigations it is possible to produce single flashes with an approximately 10 times higher light output, duration $750 \mathrm{~ns}$, electrical input 20 joules.]

Measuring beam and detector: Monochromatic light passes through the cuvette and is detected by a photomultiplier (RCA 7326). The interference filter $\mathrm{F}_{2}$ protects the multiplier from the flashes. The produced repetitive absorption changes cause voltage changes at the load resistor of the multiplier (vari-
Fig. 5. Block diagram of the repetitive ultra-short-flash photometer. Time course of the ultra-short-flash intensity (top). For details see text. able $50-100 \mathrm{k} \Omega$ ) which are amplified (broadband amplifier Keithley 105) and directed to the averager or for control tests to a normal broadband oscilloscope (hp 170A).

Out of each voltage change one "sample" is picked up at a definite time. To increase the signal/noiseratio such samples of a large number of signals are fixed and averaged. Then, after a phase shift this is repeated at a later time and so on until the entire time course of the signal has been covered and averaged.

This sampling is realized by a sampling oscilloscope (hp 185A, plug in 187C) which has a sample gatewidth of $0,4 \mathrm{~ns}^{*}$. This is followed by an integrating network (simple RC-filter). The output of the RC-filter is registered on a recorder. To collect a large number of samples out of the signals the phase shift of the sample (samplegate scan) is set slow and continuously. This is caused by an external slow ramp voltage. The trigger pulse for the sampling oscilloscope must be produced by the flash itself (in a second photomultiplier or photodiode) in order to prevent a time jitter between flash and trigger pulse.

* The sample gate-widths of the electric and the magnetic averager which has been used in 1. c. ${ }^{18,19}$ are not short enough for a time resolution between $10^{-5}$ and $10^{-7} \mathrm{sec}$. 
The essential feature of averaging is as follows. The sampling oscilloscope transforms the bandwidths of the signal and noise- and this independently. The slow scan (e.g. scanning time $T=450 \mathrm{sec}$ ) determines the output signal bandwidth (e.g. $10^{-3}$ cps) and the repetition rate $f$ determines the output noise bandwidth (e.g. $10 \mathrm{cps}$ ). The excessive noise bandwidth (compared with the signal bandwidth) is filtered out by the RC-filter. The time constant of the RC-filter (e.g. $20 \mathrm{sec}$ ) has to be low enough to prevent an influence on the signal course, but high enough to be an effective filter for the noise.

The gain in the signal-to-noise ratio is proportional to $\sqrt{f \cdot T}=\sqrt{n}$ where $n$ is the total number of pules. This is the wellknown rule for the enhancement of the signal-to-noise ratio with $\sqrt{n}$.

Such a simple arrangement - sampling oscilloscope followed by a RC-filter - represents a continuously scanning one-channel averager and was already described by Hewlett-Packard Comp. and BLETZINGER et al. ${ }^{23}$ for technical electrical measurements at repetition rates in the range of kilocycles. A similar system was used by SCHÄFER et al. for measurements of fluorescence decay times ${ }^{24}$. Here the method is used for the first time for averaging of fast absorption changes especially of photosynthetic reactions.

The application of the repetitive technique for photochemical systems is only possible when the time between two pulses is longer than the time of the rate-determining step of the overall reaction. This time is often in the order up to $1 \mathrm{sec}$. This condition has been realized because the described

23 Hewlett-Packard Comp. (private communication); P. Bletzinger, A. Garscadden, I. AlexefF, and W. D. JONES, J. sci. Instruments 42, 358 [1965].

24 F. P. SChäfer and K. Röllig, Z. physik. Chem. N.F. 40, 198 [1964].

$25 \mathrm{CH}$. WolfF, Rev. sci. Instruments, in preparation. averager works down to repetition rates in the range of 1 cps (see l. c. ${ }^{25}$ ).

Time resolution and sensitivity: The time resolution of the whole apparatus is only limited by the duration of the flash. If the ultra short flash is used, half risetimes down to

$\tau \frac{1}{2} \approx 5 \cdot 10^{-7}$ sec can be resolved (see fig. 1).

Within reasonable measuring times $(2-10$ minutes, $1000-5000$ flashes) absorption changes $\Delta I / I$ in the range of $10^{-7} \mathrm{sec}$ are detectable down to

$$
\Delta I / I \cong 0,01 \% \text { (see fig. } 2 \text { ). }
$$

The measuring equipment itself (photomultiplier, amplifier, averager) is capable to resolve absorption changes with rise times down to nanoseconds. Of course, for the excitation of such fast absorption changes the light pulses of Q-switch lasers must be used ${ }^{22}$.

A detailed description of the repetitive ultra-shortflash photometer will be published elsewhere ${ }^{25}$.

\section{Materials}

The experiments were carried out on spinach chloroplasts and cells of Chlorella vulgaris in aqueous suspensions.

The spinach chloroplasts have been prepared by fragmentation of spinach leaves with an Omnimixer at $10.000 \mathrm{cpm}$ for $10 \mathrm{sec}$ in a solution after WINGET et al. ${ }^{26}$ with addition of $10^{-2} \mathrm{M}$ ascorbate. From the sap of this preparation chloroplasts have been isolated after WINGET et al.

For the measurements with Chlorella vulgaris the strain $211-11 \mathrm{~h}$ of the Pflanzenphysiologisches Institut der Universität Göttingen was used. The algae were cultured in a solution after HUTNER with EDTA ${ }^{27}$.

${ }^{26}$ G. D. Winget, S. Izawa, and N. E. Good, Biochem. biophysic. Res. Commun. 21, 438 [1965].

27 S. H. Hutner, L. Provaolit, H. Schatz, and C. P. Haskins, Proc. Amer. phil. Soc. 94, 152 [1950]. 